\title{
Super Resolution pada Citra Udara menggunakan Convolutional Neural Network
}

\author{
MUHAMMAD EFAN ABDULFATTAH, LEDYA NOVAMIZANTI, SYAMSUL RIZAL
}

Fakultas Teknik Elektro, Telkom University, Indonesia

Email: muhammadefan@student.telkomuniversity.ac.id

Received 28 Juni 2020 | Revised 16 Juli 2020 | Accepted 24 Juli 2020

\begin{abstract}
ABSTRAK
Bencana di Indonesia didominasi oleh bencana hidrometeorologi yang mengakibatkan kerusakan dalam skala besar. Melalui pemetaan, penanganan yang menyeluruh dapat dilakukan guna membantu analisa dan penindakan selanjutnya. Unmanned Aerial Vehicle (UAV) dapat digunakan sebagai alat bantu pemetaan dari udara. Namun, karena faktor kamera maupun perangkat pengolah citra yang tidak memenuhi spesifikasi, hasilnya menjadi kurang informatif. Penelitian ini mengusulkan Super Resolution pada citra udara berbasis Convolutional Neural Network (CNN) dengan model DCSCN. Model terdiri atas Feature Extraction Network untuk mengekstraksi ciri citra, dan Reconstruction Network untuk merekonstruksi citra. Performa DCSCN dibandingkan dengan Super Resolution CNN (SRCNN). Eksperimen dilakukan pada dataset Set5 dengan nilai scale factor 2, 3 dan 4. Secara berurutan SRCNN menghasilkan nilai PSNR dan SSIM sebesar $36.66 d B / 0.9542,32.75 d B / 0.9090$ dan $30.49 d B / 0.8628$. Performa DCSCN meningkat menjadi 37.614dB / 0.9588, 33.86 dB / 0.9225 dan 31.48 dB / 0.8851.
\end{abstract}

Kata kunci: citra udara, deep learning, super resolution

\begin{abstract}
Disasters in Indonesia are dominated by hydrometeorological disasters, which cause large-scale damage. Through mapping, comprehensive handling can be done to help the analysis and subsequent action. Unmanned Aerial Vehicle (UAV) can be used as an aerial mapping tool. However, due to the camera and image processing devices that do not meet specifications, the results are less informative. This research proposes Super Resolution on aerial imagery based on Convolutional Neural Network (CNN) with the DCSCN model. The model consists of Feature Extraction Network for extracting image features and Reconstruction Network for reconstructing images. DCSCN's performance is compared to CNN Super Resolution (SRCNN). Experiments were carried out on the Set5 dataset with scale factor values 2, 3, and 4. The SRCNN sequentially produced PSNR and SSIM values of 36.66dB / 0.9542, 32.75dB / 0.9090 and 30.49dB / 0.8628. DCSCN's performance increased to $37,614 d B / 0.9588,33.86 d B / 0.9225$ and $31.48 d B$ / 0.8851 .
\end{abstract}

Keywords: aerial imagery, deep learning, super resolution 
Abdulfattah, dkk

\section{PENDAHULUAN}

Secara geografis, Negara Kesatuan Republik Indonesia termasuk dalam kategori iklim tropis dengan perubahan cuaca yang terjadi di setiap tahunnya. Kondisi tersebut menjadikan Indonesia rentan terhadap ancaman bencana hidrometeorologi, seperti: angin puting beliung, kebakaran hutan, banjir, dan tanah longsor. Badan Nasional Penanggulangan Bencana (BNPB) menyatakan bahwa pada tahun 2019, bencana hidrometeorologi masih mendominasi dengan prediksi sebesar $95 \%$ dari total bencana yang disebabkan oleh kerusakan pada Daerah Aliran Sungai (DAS) (Welle, 2019). Untuk mengefektifkan proses identifikasi, diperlukan pemetaan terhadap area yang terkena dampak bencana. Salah satu cara yang dapat dilakukan dengan bantuan Unamanned Aerial Vehicle (UAV) atau pesawat tanpa awak. UAV mampu terbang dengan kendali remote contro/maupun terbang secara autonomouos (Shahmoradi, 2020). Namun, pada suatu kondisi terdapat kemungkinan adanya permasalahan pada hasil pemetaan atau fotogrametri. Hal ini karena keterbatasan spesifikasi kamera maupun perangkat pengolahan citra yang digunakan. Akibatnya, informasi yang dapat dipahami oleh manusia secara visual menjadi kurang detail. Oleh karena itu, diusulkanlah metode Super Resolution untuk memperjelas tampilan citra (Dong, dkk, 2015)(Tong, dkk, 2017).

Sistem Super Resolution yang dibuat mampu merekonstruksi ukuran citra menjadi lebih besar. Sehingga, mata manusia dapat mencerna detail informasi pada citra tersebut dengan lebih baik. Model yang digunakan adalah Deep CNN with Skip Connection and Network In Network (DCSCN), yang terdiri atas Feature Extraction Network dengan fitur Skip Connection pada hidden layer untuk mengekstraksi ciri local dan ciri global dari citra masukan. Reconstruction Network dengan fitur Network In Network (NIN) atau parallel CNN (Lin, dkk, 2014) berfungsi untuk merekonstruksi citra berdasarkan pada ciri yang didapatkan dari Feature Extraction Network. Skip connection digunakan pada awal model untuk memuat hasil pre processing menggunakan interpolasi bicubic (Fadnavis, 2014) berdasarkan pada nilai scale factor tertentu. Hasil pre-processing tersebut nantinya digabungkan dengan hasil dari Reconstruction Network, sehingga diperoleh citra rekonstruksi (Yamanaka, dkk, 2017). Chao Dong, et al mengusulkan model Super Resolution CNN (SRCNN)._Model tersebut terdiri atas struktur Patch Extraction and Representation, Non-Linear Mapping dan Reconstruction (Dong, dkk, 2015). Dalam naskah ini, kami mengusulkan Super Resolution yang diterapkan pada citra udara menggunakan model DCSCN yang di latih menggunakan dataset BSD200 dan 100 citra udara milik penulis, sehingga total dataset latih berisi 300 citra. Dataset baru tersebut dinamakan dengan Aero_bsd300 yang pada tahapan prosesnya diaugmentasi hingga delapan kali.

\section{METODOLOGI}

\subsection{Super Resolution}

Super Resolution merupakan contoh dari penerapan pengolahan citra digital yang ditujukan untuk merekonstruksi citra dengan resolusi rendah dan detail minim menjadi citra resolusi tinggi dengan detail yang lebih kentara. Ukuran citra hasil rekonstruksi bergantung pada nilai

scale factor yang digunakan. Melalui Super Resolution, diharapkan informasi yang terdapat pada citra dapat dikenali secara lebih baik oleh mata manusia (Dong, dkk, 2015) (Tong, dkk, 2017) (Yamanaka, dkk, 2017) (Ahn, dkk, 2019) (Sun, dkk, 2019).

\subsection{Convolutional Neural Network}

CNN termasuk dalam algoritma Deep Learning yang bekerja secara feed-forward. Pada umumnya, CNN diaplikasikan untuk bidang Computer Vision, misalnya: deteksi objek, klasifikasi objek dan lain-lain (Suyanto, 2018)(Heaton, 2015). CNN memiliki beberapa 
macam layer, yaitu: input layer, output layer, serta hidden layeryang terdiri dari convolutional layer, pooling layer dan fully-connected layer. Setiap layer tersebut terdiri atas array tiga dimensi, yaitu: lebar, tinggi, dan kedalaman. Lebar dan tinggi merupakan ukuran matriks, sedangkan kedalaman mengacu pada jumlah kanal warna citra atau dalam bagian yang lain dapat mewakili jumlah filter. Jumlah hidden layer pada CNN bergantung pada arsitektur yang digunakan. Contoh arsitektur yang marak digunakan adalah VGGNet (Simonyan, dkk, 2015), GoogleNet dan ResNet (Sewak, dkk, 2018). Gambar 1 merupakan lapisan-lapisan yang terdapat pada CNN (Stenroos, 2017).

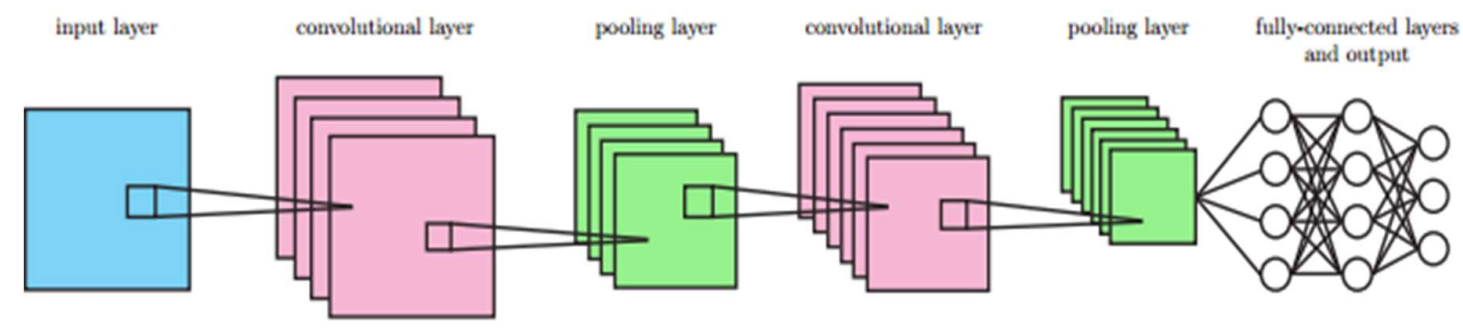

Gambar 1. Lapisan-lapisan pada CNN

\subsection{Residual Block}

Residual Block merupakan suatu kumpulan fungsi yang didalamnya terdapat fitur Skip Connection pada arsitektur Residual Network (ResNet). Adanya fitur tersebut, ResNet telah membuktikan efektivitasnya setelah menjadi juara pada kompetisi ILSVRC 2015. Skip connection dianggap mampu mengatasi permasalahan galat pelatihan dan evaluasi yang tinggi karena underfitting yang disebabkan oleh vanishing gradient pada model dengan lapisan yang sangat dalam (Géron, dkk, 2017) (Tong, dkk, 2017) (Sewak, dkk, 2018). Gambar 2 merupakan contoh representasi dari residual block (Géron, 2017).

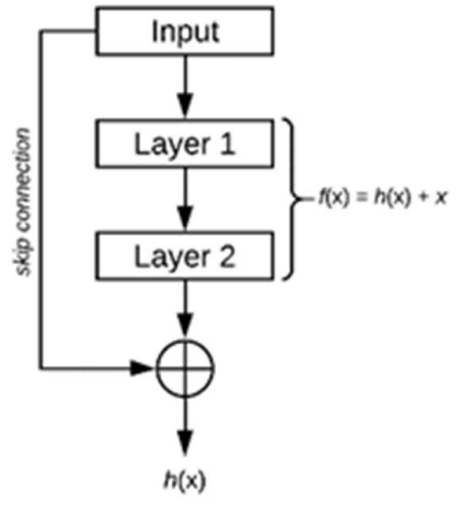

\section{Gambar 2. Contoh Residual Block}

\subsection{Network In Network}

Network in Network (NIN) merupakan suatu struktur jaringan dalam CNN yang dapat digunakan untuk meningkatkan non-linearitas pada citra yang hendak diekstraksi cirinya. NIN bekerja seperti lapisan konvolusional yang setelahnya diaplikasikan fungsi aktivasi ReLU untuk mendapatkan nilai weight yang non-linear. Dalam struktur NIN terdapat kerne/konvolusi $1 \times 1$ yang disusun sebanyak beberapa bagian (Lin, dkk, 2014).

\subsection{Rancangan Sistem}

Bagian ini memaparkan sistematika untuk mendapatkan citra rekonstruksi dengan resolusi tinggi dari citra resolusi rendah yang diambil dari udara. Tahapannya diawali dengan membuat dataset latih dan dataset evaluasi. Lalu, tahap pre-processing yang dibarengi dengan tahap 
pelatihan model yang telah dirancang. Kemudian dilakukan tahap evaluasi model hasil pelatihan dengan beberapa sampel citra dari dataset evaluasi. Setelah didapatkan model yang sesuai dengan skenario, model dapat diujikan. Pengujian dilakukan pada citra resolusi rendah untuk merekonstruksi citra tersebut menjadi citra dengan ukuran tertentu sesuai dengan nilai scale factor yang digunakan. Gambar 3 merupakan representasi dari skenario pelatihan.

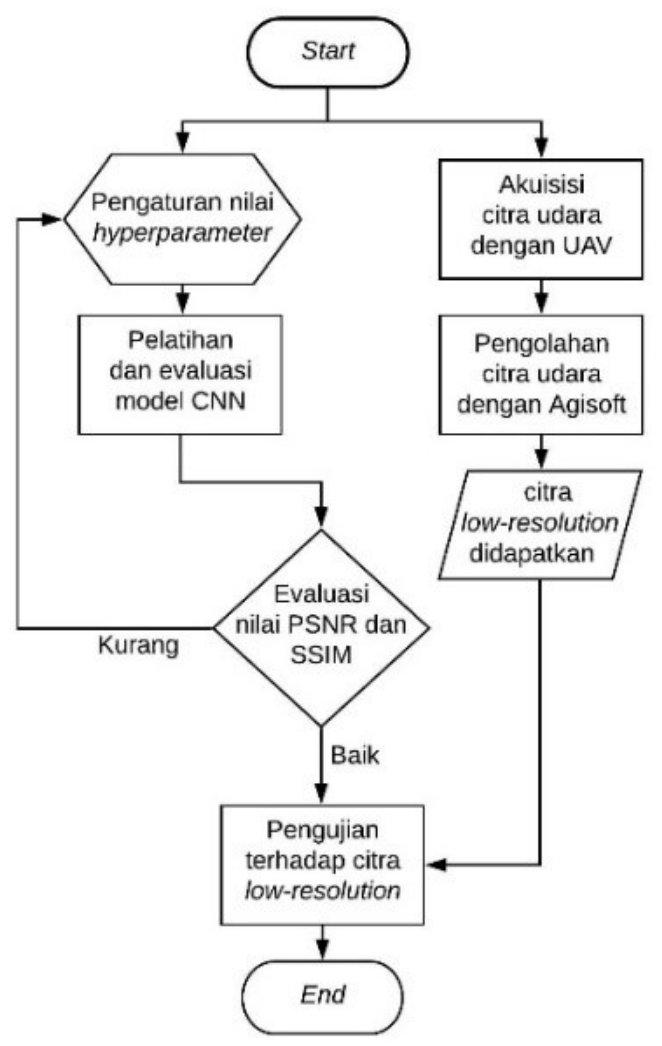

Gambar 3. Skenario Penelitian

\subsection{Pengumpulan Dataset}

Pada penelitian ini, sampel citra dibagi menjadi dua jenis dataset, yaitu: dataset latih dan dataset evaluasi. Dataset latih berisi 100 sampel citra udara milik penulis yang diambil melalui UAV, dan 200 sampel citra dari dataset BSD200 yang dapat diakses pada laman https://www2.eecs.berkeley.edu/Research/Projects/CS/vision/bsds. Total terdapat 300 sampel citra pada dataset latih yang dinamakan Aero_bsd300. Sedangkan, pada dataset evaluasi terdiri dari 10 sampel citra udara milik penulis, dinamakan dataset Aero10. Selain itu, penelitian ini juga memanfaatkan dataset Set5 yang berisi 5 sampel citra yang dapat diakses pada laman https://www.kaggle.com/II01dm/set-5-14-super-resolution-dataset. Dataset Set5 ini digunakan sebagai bahan evaluasi antara model yang diusulkan dengan metode rekonstruksi citra lainnya.

\subsection{Akuisisi Citra}

Akuisisi citra udara dilakukan menggunakan kamera yang dipasang pada bagian bawah badan UAV, dengan posisi lensa menghadap tepat ke bawah. Tahapan yang harus dilakukan, yaitu:

\section{Tahap Perencanaan Misi Pemetaan}

Diawali dengan mengatur waypoint menggunakan aplikasi Mission Planner (MP) sebagai pemandu arah terbang UAV. Pengaturan waypoint dilakukan dengan masuk ke menu Flight 
Plan, lalu altitude diatur pada angka 150m dan luas cakupan diatur dengan menempatkan titik waypoint pada peta yang ditampilkan oleh aplikasi MP. Flight plan yang berisi waypoint telah diatur sedemikian rupa untuk pelaksanaan misi pemetaan di daerah Lapangan TNI GratiPasuruan yang direpresentasikan oleh Gambar 4.

\section{Tahap Geo Tagging Citra Udara}

Geo Tagging merupakan tahap menyatukan potongan citra udara dengan titik koordinat ketika citra udara tersebut diambil. Titik koordinat didapatkan dari modul Global Positioning System (GPS) yang terintegrasi dengan Flight Controller (FC). Untuk mengunduh data log titik koordinat dilakukan dengan menghubungkan antara FC dengan laptop. Kemudian, aplikasi MP dibuka dan data log dapat diunduh dari opsi yang tersedia pada tampilan menu utama yang bernama DataFlash Log. Selanjutnya, pilih opsi Download DataFlash Log Via Mavlink, sehingga file akan tersimpan pada folder Document di laptop. Setelah data log didapatkan, maka titik koordinat yang ada di dalamnya digabungkan dengan potongan citra udara dengan cara masuk ke menu temp yang dapat diakses menggunakan hotkey ctrl+f. Masuk ke menu Geo ref images, untuk memasukan data log yang telah diunduh pilih Browse Log. Opsi Browse Pictures untuk memasukan potongan citra udara. Selanjutnya pilih opsi Pre-process, dan pilih opsi GeoTag Images. Pada tahap ini, potongan citra udara telah disatukan dengan titik koordinat dan disimpan di dalam folder baru yang bernama "geotagged". Gambar 5 menunjukkan titik koordinat nyata dalam pengambilan citra udara. Data berupa estimasi galat dalam satuan jarak $(\mathrm{m})$ terhadap titik koordinat pengambilan citra yang diatur melalui waypoint di MP.

\section{Tahap Pengolahan Citra Udara}

Pengolahan menggunakan aplikasi Agisoft Metashape pada semua potongan citra udara yang telah ditanami titik koordinat. Semua citra dipanggil dengan memilih opsi Add Photos pada tampilan Workspace. Kemudian, menuju toolbar Workflow untuk menyatukan potongan citra udara dengan memilih opsi Align Photos. Hasil dari pemrosesan kemudian di-export dalam format jpg (*.jpg). Citra udara ini digunakan sebagai bahan pengujian pada sistem Super Resolution yang sebelumnya dikonversi terlebih dahulu ke format bmp (*.bmp).

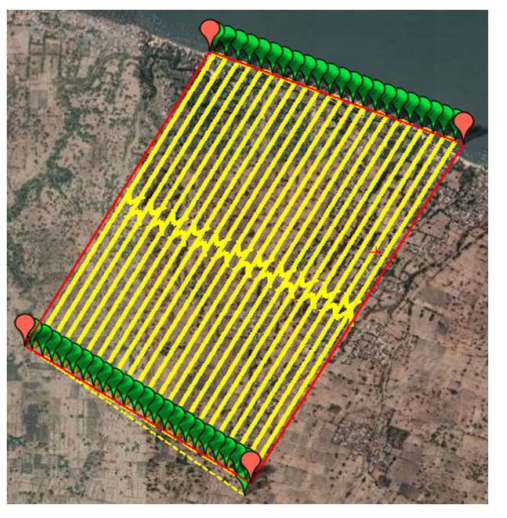

Gambar 4. Waypoint Misi Pemetaan

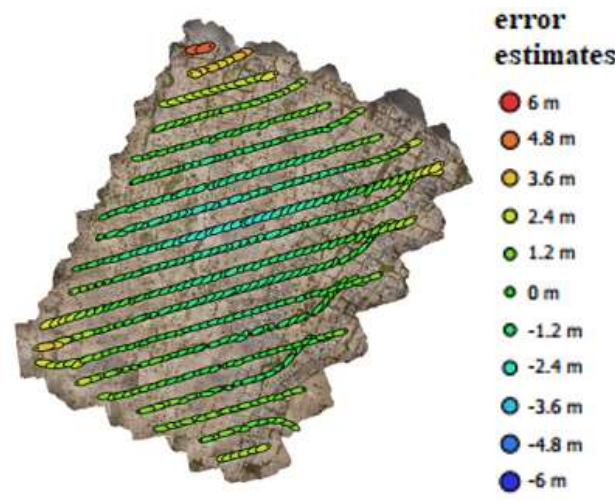

Gambar 5. Titik Koordinat Pengambilan Citra

\subsection{Super Resolution}

Sistematika untuk mendapatkan citra rekonstruksi dengan model DCSCN direpresentasikan oleh Gambar 6. Secara keseluruhan, sistematika yang dijalankan untuk mendapatkan citra rekonstruksi dengan resolusi tinggi dibagi menjadi dua tahap, yaitu: tahap pelatihan dan evaluasi, serta tahap pengujian. 


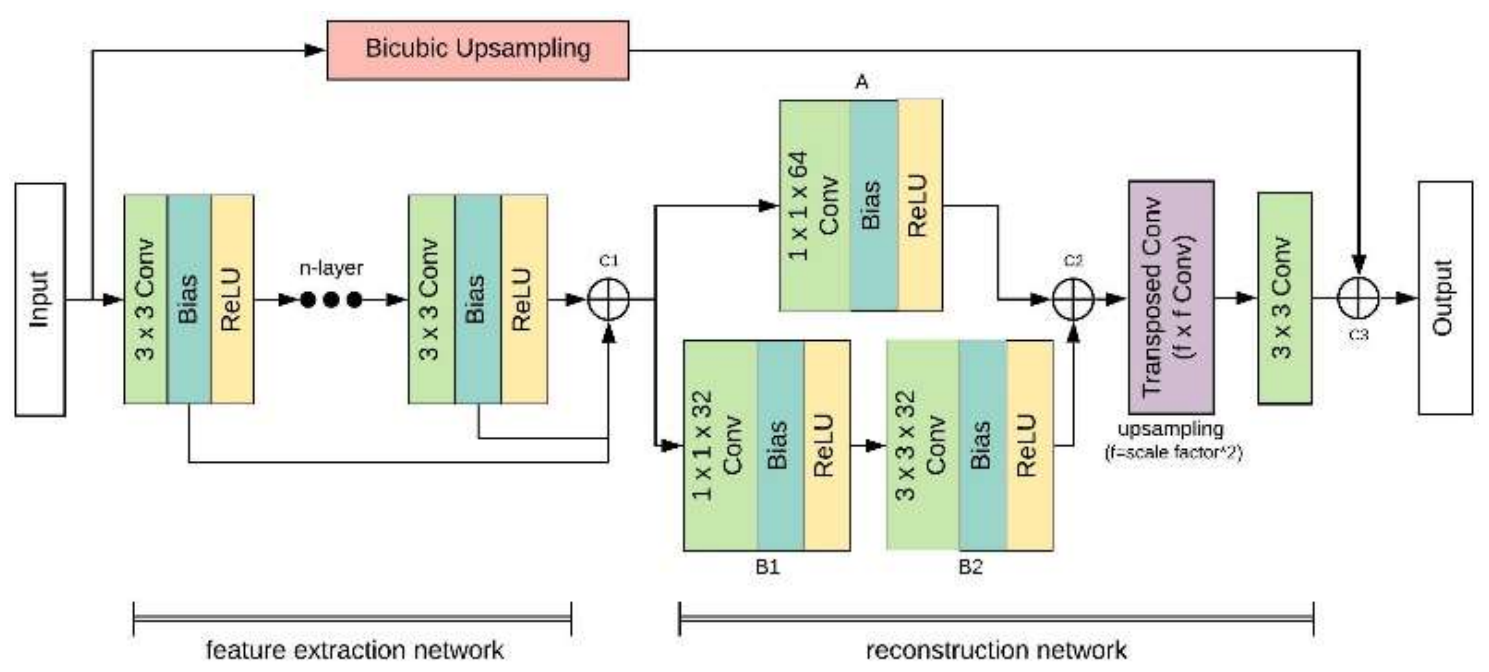

Gambar 6. Blok Desain Sistem

\subsubsection{Tahap Pelatihan dan Evaluasi}

Sistem Super Resolution yang dibuat dilatih dan dievaluasi menggunakan dataset yang berisi sampel citra Rec-Green-Blue (RGB) dengan format *.bmp. Arsitektur yang dirancang, terdiri dari: feature extraction network dan reconstruction network. Proses yang terjadi pada masingmasing jaringan, yaitu:

\section{Feature Extraction Network}

Tahap pertama, yaitu pre-processing untuk mendapatkan citra resolusi rendah. Tahap ini dilakukan terhadap dataset evaluasi melalui proses down-sampling lalu up-sampling menggunakan interpolasi bicubic dengan nilai scale factor tertentu. Hasilnya dilompatkan ke titik concatenate ketiga, yang dinamakan dengan skip connection. Kemudian, sampel citra dari dataset latih mulai dimasukkan ke lapisan masukan sebelum ke lapisan tersembunyi. Di dalam lapisan tersembunyi, terdapat proses konvolusi antara citra masukan dengan sejumlah filter yang berukuran $3 \times 3$, dan rentang nilainya telah diatur berdasarkan pada He Initializer (Patel, dkk, 2018). Hasil dari konvolusi kemudian diseleksi oleh fungsi aktivasi Rectified Linear Unit (ReLU) (Wibawa, 2016), lalu ditampung pada weight kerne/ baru. Pada proses selanjutnya, weight kerne/ tersebut ada yang dikonvolusikan lagi dengan filter berdasarkan pada He initializer, serta ada yang dilompatkan menuju titik concatenation pertama. Proses tersebut terjadi di setiap layer yang diterapkan pada arsitektur. Tujuan dari weight kerne/ baru yang diteruskan ke setiap lapisan tersembunyi adalah untuk mengekstraksi ciri loca/dari setiap citra masukan. Sedangkan skip connection yang ada di setiap layer berguna untuk mengirimkan hasil ekstraksi ciri global dari setiap sampel citra masukan, dan dikirim menuju titik concatenation pertama.

\section{Reconstruction Network}

Setelah weight kerne/ yang berisi data ciri didapatkan, tahap pelatihan dilanjutkan dengan reconstruction network untuk merekonstruksi citra. Pada jaringan ini, dilakukan proses konvolusi dan seleksi oleh ReLU, seperti halnya pada proses di feature extraction network. Namun, di bagian ini menggunakan konfigurasi seperti Network in Network (NIN). Sehingga, terdapat dua cabang, yaitu: cabang A berisi satu proses konvolusi dengan 64 filter berukuran $1 \times 1$ lalu seleksi oleh ReLU, dan cabang B berisi dua proses konvolusi lalu seleksi oleh ReLU. Proses B1 menggunakan 32 filter berukuran $1 \times 1$, dan proses B2 menggunakan 32 filter berukuran $3 \times 3$. Hasil dari setiap cabang tersebut kemudian mengalir ke titik concatenation kedua untuk digabungkan. Setelahnya, nilai weight kerne/yang terbaru diarahkan menuju titik 
concatenation ketiga untuk ditambahkan dengan citra hasil interpolasi bicubic, sehingga diperoleh citra hasil rekonstruksi. Seluruh proses tersebut dilakukan secara iteratif sebanyak jumlah epoch, dan keluaran yang didapatkan dari tahap pertama ini adalah nilai parameter PSNR dan SSIM yang dijadikan sebagai bahan untuk mengevaluasi model yang telah dilatih. Nilai learning rate yang ditetapkan berpengaruh pada nilai weight kernel. Dengan diterapkannya decay pada learning rate, maka model yang dirancang mampu mencapai titik konvergensi dengan lebih cepat dan simpangan saat osilasi terjadi menjadi lebih pendek.

\subsubsection{Tahap Pengujian}

Tahapan pengujian dilakukan setelah tahap evaluasi model pada masing-masing scale factor selesai dilakukan. Nilai weight yang telah didapatkan dari tahap pelatihan digunakan untuk tahap pengujian. Keluaran dari tahap ini adalah hasil rekonstruksi citra udara untuk dievaluasi secara visual. Fotogrametri yang digunakan sebagai bahan pengujian di cuplik dengan ukuran tertentu dan dinamakan dengan image_20.

\subsection{Performa Sistem}

\subsubsection{Peak Signal-to-Noise Ratio}

Peak Signal-to-Noise Ratio (PSNR) merupakan nilai parameter dalam pengolahan citra yang menyatakan besarnya galat pada citra dengan satuan dB. Mean Square Error (MSE) merupakan nilai parameter yang menyatakan galat rata-rata hasil perbandingan antara citra asli dengan citra hasil rekonstruksi. Persamaan 1 dan 2 merupakan perhitungan untuk mendapatkan nilai PSNR dan Mean Square Error(MSE) (Nurfitri, dkk, 2016).

$$
\begin{gathered}
\mathrm{PSNR}=10 \log _{10} \frac{\mathrm{s}^{2}}{\mathrm{MSE}} \\
\mathrm{MSE}=\frac{1}{\mathrm{~N}} \sum_{i=0}^{N}\left(y_{i}-\hat{\mathrm{y}}_{i}\right)^{2}
\end{gathered}
$$

dengan s adalah nilai intensitas maksimum dari ukuran bit citra yang diolah. Pada tulisan ini, citra menggunakan layer RGB, sehingga nilai s adalah 255. Peubah N merupakan ukuran resolusi citra, $y$ adalah nilai intensitas pada tiap piksel citra asli, serta $\hat{y}$ merupakan nilai intensitas pada citra hasil rekonstruksi (Budiman, dkk, 2015).

\subsubsection{Structural Similarity Index Measurement}

Structural Similarity Index Measurement (SSIM) merupakan nilai parameter yang menyatakan tingkat kemiripan antara citra asli dengan citra hasil rekonstruksi. Parameter ini digunakan pada tahap evaluasi model DCSCN untuk menentukan model dengan pengaturan mana yang mampu merekonstruksi citra dengan lebih baik. Rentang nilai SSIM dibatasi dari 0 hingga 1. Semakin besar nilai SSIM maka tingkat kemiripan semakin tinggi (Nurfitri, dkk, 2016).

\section{HASIL DAN PEMBAHASAN}

Bab ini memaparkan hasil penelitian yang diperoleh dari setiap skenario yang dijalankan, disertai dengan analisis evaluasi hasil yang diperoleh. Tahap evaluasi sistem Super Resolution dilakukan berdasarkan pada parameter PSNR dan SSIM. Tahap evaluasi dilakukan dalam beberapa tahap sesuai dengan skenario yang telah dibuat, guna menentukan pengaturan yang paling baik dalam efisiensi waktu komputasi, serta nilai parameter PSNR dan SSIM yang lebih tinggi. Setiap skenario yang dijalankan, dievaluasi berdasarkan pada nilai scale factor. Hal ini ditujukan agar mendapatkan citra hasil rekonstruksi yang terbaik pada masing-masing nilai scale factor. Nilai scale factor yang diujikan, yaitu: 2, 3, dan 4. 


\subsection{Tahap Pre-Processing}

Pada tahap pre-processing, citra masukan akan direduksi ukurannya berdasarkan pada nilai scale factor tertentu, kemudian dikembalikan ke ukuran semula menggunakan interpolasi bicubic guna mendapatkan citra resolusi rendah. Tabel 1 merupakan hasil evaluasi dari tahap pre-processing. Citra ground-truth dan hasil dari tahap ini direpresentasikan oleh Gambar 7. Citra tersebut merupakan salah satu sampel dari dataset Aero10.

Tabel 1. Hasil Evaluasi Tahap Pre-processing

\begin{tabular}{|c|c|c|c|}
\hline Citra & Scale Factor & PSNR & SSIM \\
\hline \multirow{3}{*}{ image_20 } & 2 & 36.460 & 0.9414 \\
\cline { 2 - 4 } & 3 & 33.401 & 0.8864 \\
\cline { 2 - 4 } & 4 & 31.893 & 0.8514 \\
\hline
\end{tabular}

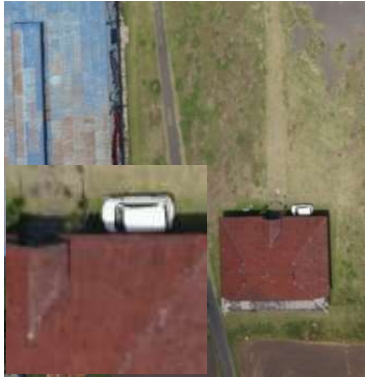

(a)

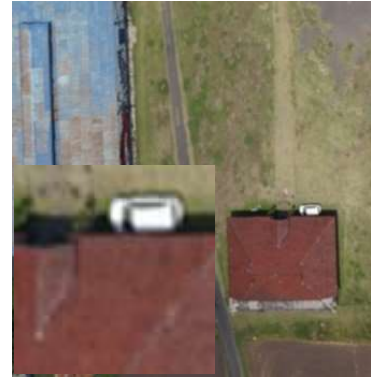

(b)

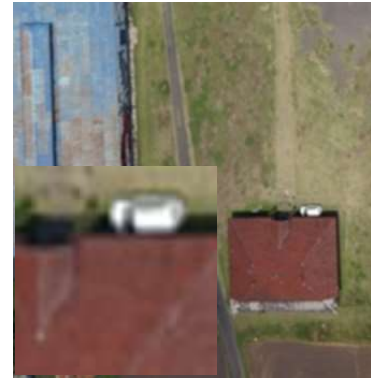

(c)

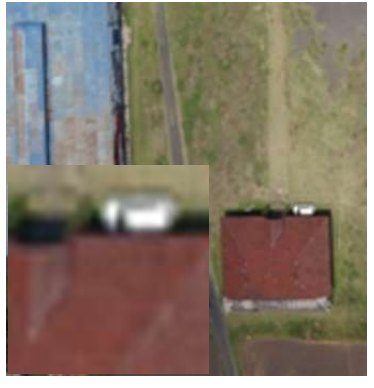

(d)

Gambar 7. Image_20 (a) Ground-Truth, (b) Scale Factor Dua (c) Scale FactorTiga (d) Scale Factor Empat

\subsection{Evaluasi Augmentasi Dataset}

Pada skenario pertama, dilakukan evaluasi terhadap jumlah sampel citra pada masing-masing dataset latih, yaitu: dataset awal maupun dataset hasil augmentasi. Inisialisasi parameter global ditunjukkan pada Tabel 2.

Tabel 2. Parameter Global pada Skenario Pertama

\begin{tabular}{|l|c|}
\hline \multicolumn{1}{|c|}{ Parameter } & Nilai \\
\hline Jumlah layer & 7 \\
\hline Jumlah epoch & 150 \\
\hline Jumlah filter ekstraksi ciri awal & 192 \\
\hline Jumlah filter ekstraksi ciri akhir & 48 \\
\hline Peubah decay filter tiap layer & 1.5 \\
\hline Learning rate awal & 0.002 \\
\hline Learning rate akhir & 0.0005 \\
\hline Peubah decay learning rate tiap 50 epoch & 0.5 \\
\hline
\end{tabular}

Rincian dataset yang dilakukan pada skenario pertama, yaitu:

1. Dataset Aero_bsd300 yang berisi 300 sampel citra.

2. Dataset Aero_bsd300_2 dengan augmentasi secara horizontal, maka didapatkan 600 sampel citra.

3. Dataset Aero_bsd300_4 dengan augmentasi secara horizontal, vertical dan verticalhorizontal, maka didapatkan 1200 sampel citra. 
4. DatasetAero_bsd300_6 dengan augmentasi secara horizontal, vertical, vertical-horizontal, single clock-wise rotation dan double clock-wise rotation, maka didapatkan 1800 sampel citra.

5. DatasetAero_bsd300_8 dengan augmentasi secara horizontal, vertical, vertical-horizontal, single clock-wise rotation, double clock-wise rotation, single clock-wise rotation-vertical dan double clock-wise rotation-vertical, maka didapatkan 2400 sampel citra.

Data perbandingan berdasarkan scale factor disajikan pada Gambar 8.

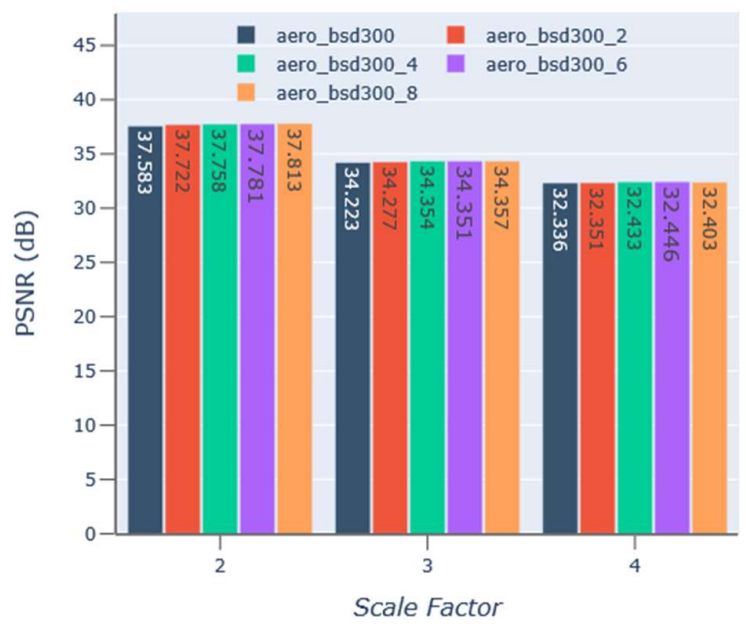

(a)

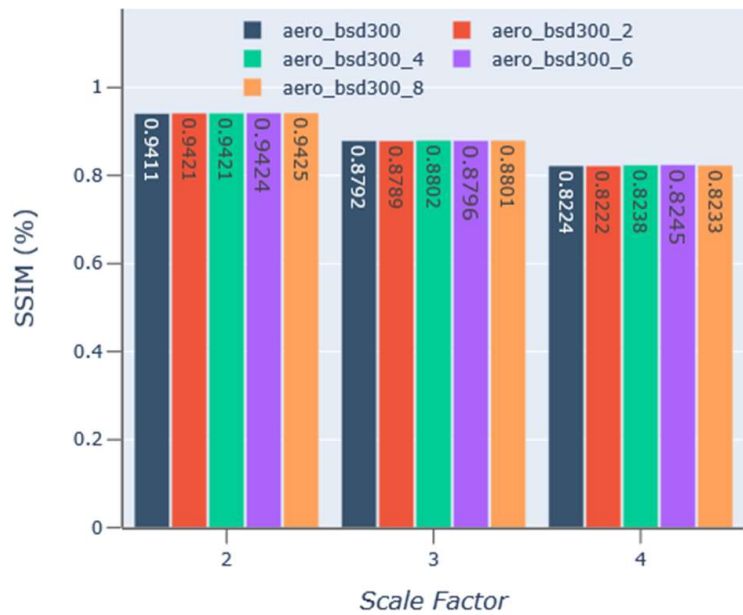

(b)

Gambar 8. Hasil Evaluasi Nilai Scale Factor terhadap Performa (a) PSNR (b) SSIM

Berdasarkan Gambar 8, diperoleh bahwa dataset Aero_bsd300_6 dan Aero_bsd300_8 mendapatkan nilai tertinggi pada parameter PSNR dan SSIM, dengan selisih di antara keduanya tidak terlampau jauh. Namun, terdapat perbedaan yang mencolok terhadap konsumsi waktu yang dibutuhkan pada tahap pelatihan, seperti yang ditunjukkan oleh Gambar 9. Dataset Aero_bsd300_6 dipilih untuk diterapkan pada skenario berikutnya, karena dinilai lebih efisien dalam waktu komputasi.

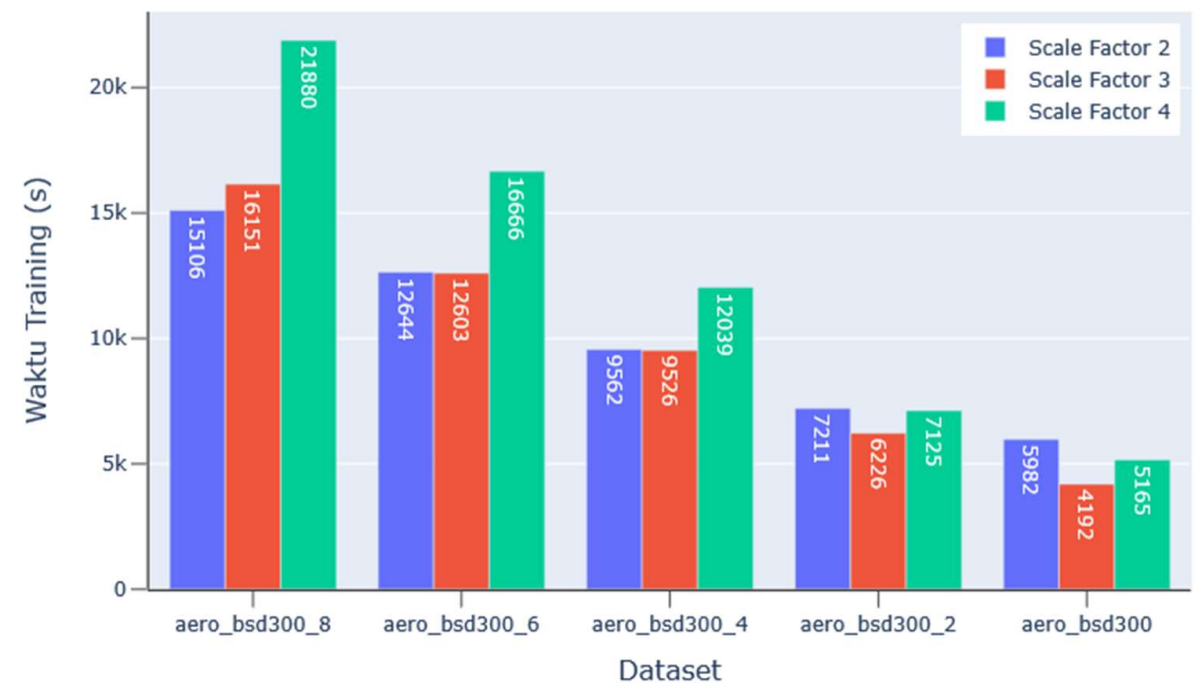

Gambar 9. Hasil Evaluasi Waktu Training terhadap Dataset Latih 


\subsection{Evaluasi Jumlah Layer}

Pada skenario kedua, parameter yang dievaluasi merupakan jumlah layer pada feature extraction network. Pengujian dilakukan pada dataset Aero_bsd300_6 dan nilai scale factor 4. Tabel 4 merupakan inisialisasi parameter globalpada skenario kedua.

Tabel 4. Parameter Global pada Skenario Kedua

\begin{tabular}{|l|c|}
\hline \multicolumn{1}{|c|}{ Parameter } & Nilai \\
\hline Jumlah epoch & 90 \\
\hline Jumlah filter ekstraksi ciri awal & 192 \\
\hline Jumlah filter ekstraksi ciri akhir & 48 \\
\hline Peubah decay filter tiap layer & 1.5 \\
\hline Learning rate awal & 0.002 \\
\hline Learning rate akhir & 0.0005 \\
\hline Peubah decay learning rate tiap 50 epoch & 0.5 \\
\hline
\end{tabular}

Tahap evaluasi dilakukan dengan lima macam jumlah layer yang berbeda. Oleh karena itu, terdapat perbedaan pada distribusi jumlah filter di setiap layer, yaitu:

1. Pada model dengan lima buah layer, distribusi jumlah filter berurutan dari layer pertama hingga layer terakhir, yaitu: 192, 134, 101, 73 dan 48.

2. Pada model dengan enam buah layer, distribusi jumlah filter berurutan dari layer pertama hingga layer terakhir, yaitu: 192, 142, 113, 89, 67 dan 48.

3. Pada model dengan tujuh buah layer, distribusi jumlah filter berurutan dari layer pertama hingga layer terakhir, yaitu: 192, 148, 122, 101, 82, 64 dan 48.

4. Pada model dengan delapan buah layer, distribusi jumlah filter berurutan dari layer pertama hingga layer terakhir, yaitu: 192, 152, 129, 110, 92, 76, 62 dan 48.

5. Pada model dengan sembilan buah layer, distribusi jumlah filter berurutan dari layer pertama hingga layer terakhir, yaitu: 192, 156, 134, 117, 101, 86, 73, 60 dan 48.

Tabel 5. Pengaruh Jumlah Layer terhadap Performa

\begin{tabular}{|c|c|c|}
\hline Jumlah Layer & PSNR (dB) & SSIM \\
\hline 5 & 32.372 & 0.8234 \\
\hline 6 & 32.41 & 0.8238 \\
\hline 7 & 32.42 & 0.8238 \\
\hline 8 & 32.442 & 0.8244 \\
\hline 9 & 32.461 & 0.8246 \\
\hline
\end{tabular}

Tabel 5 merupakan hasil eksperimen dari tahap evaluasi pertama hingga kelima. Semakin banyak jumlah layer, maka nilai parameter PSNR dan SSIM menjadi relatif lebih tinggi. Hal ini dikarenakan semakin banyak fitur atau ciri local maupun globalyang diekstraksi oleh model dari citra latih, maka hasil rekonstruksi Super Resolution meningkat dari segi visual maupun nilai PSNR dan SSIM. Oleh karena itu, model dengan 9 layer dipilih untuk diterapkan pada skenario berikutnya.

\subsection{Evaluasi Jumlah Filter}

Pada skenario ketiga, parameter yang dievaluasi merupakan jumlah filter awal pada feature extraction network. Berdasarkan hasil pengujian tahap sebelumnya, maka pada tahap evaluasi ini dilakukan dengan dataset Aero_bsd300_6, dan 9 layer. Selain itu, nilai scale factor 4, dan iterasi sebanyak 90 epoch. Tabel 6 merupakan nilai asumsi parameter global pada skenario ketiga. 
Tabel 6. Parameter Globalpada Skenario Ketiga

\begin{tabular}{|l|c|}
\hline \multicolumn{1}{|c|}{ Parameter } & Nilai \\
\hline Jumlah filter ekstraksi ciri akhir & 48 \\
\hline Peubah decay filter tiap layer & 1.5 \\
\hline Learning rate awal & 0.002 \\
\hline Learning rate akhir & 0.0005 \\
\hline Peubah decay learning rate tiap 50 epoch & 0.5 \\
\hline
\end{tabular}

Tahap evaluasi dilakukan dengan tiga macam jumlah filter yang berbeda. Sehingga, terdapat perbedaan pada distribusi jumlah filter pada masing-masing layer di feature extraction network. Rincian distribusi jumlah filter, sebagai berikut:

1. Pada model dengan 96 buah filter awal, distribusi jumlah filter berurutan dari layerpertama hingga layer terakhir, yaitu: 96, 84, 76, 71, 65, 60, 56, 52 dan 48 buah.

2. Pada model dengan 144 buah filter awal, distribusi jumlah filter berurutan dari layer pertama hingga layer terakhir, yaitu: 144, 120, 105, 94, 83, 73, 64, 56 dan 48 buah.

3. Pada model dengan 192 buah filter awal, distribusi jumlah filter berurutan dari layer pertama hingga layer terakhir, yaitu: 192, 156, 134, 117, 101, 86, 73, 60 dan 48 buah.

Tabel 7. Pengaruh Jumlah Filter terhadap Performa

\begin{tabular}{|c|c|c|}
\hline Jumlah Filter & PSNR (dB) & SSIM \\
\hline 96 & 32.442 & 0.8241 \\
\hline 144 & 32.449 & 0.8247 \\
\hline 192 & 32.461 & 0.8246 \\
\hline
\end{tabular}

Tabel 7 merupakan hasil pengujian dari pengaruh jumlah filter terhadap Performa sistem. Berdasarkan hasil dari seluruh evaluasi, diperoleh bahwa semakin banyak jumlah filter, maka nilai parameter PSNR dan SSIM menjadi relatif lebih tinggi. Hal ini dikarenakan semakin banyaknya fitur atau ciri yang diekstraksi oleh model dari citra latih, maka hasil rekonstruksi Super Resolution pun meningkat. Penurunan nilai SSIM terjadi pada model dengan 192 filter. Hal tersebut dikarenakan adanya osilasi pada nilai gradien saat proses menuju titik konvergensi. Jumlah epoch yang sedikit menyebabkan nilai bobot yang didapatkan berhenti di titik tersebut. Oleh karena itu, berdasarkan pada nilai PSNR yang didapatkan, model dengan 192 buah filter dipilih untuk diterapkan pada skenario berikutnya.

\subsection{Evaluasi Jumlah Epoch}

Pada skenario keempat, parameter yang dievaluasi merupakan jumlah epoch yang digunakan pada tahap pelatihan model. Hal ini berpengaruh terhadap jumlah iterasi yang dibutuhkan oleh learning rate untuk melakukan transisi. Tahap evaluasi ini dilakukan dengan dataset Aero_bsd300_6, sembilan layer dan 192 filter awal pada feature extraction network. Hal ini didasarkan pada hasil yang didapatkan dari skenario pengujian sebelumnya, dan nilai scale factor 4. Diterapkan pula inisialisasi parameter global, seperti yang ditunjukkan pada Tabel 4. Tahap evaluasi dilakukan dengan lima macam jumlah epoch yang berbeda, maka terdapat perbedaan pada jumlah epoch yang diperlukan untuk melakukan transisi learning rate, yaitu:

1. Pada evaluasi pertama menggunakan 60 epoch, maka decay terjadi setiap 20 epoch.

2. Pada evaluasi kedua menggunakan 90 epoch, maka decay terjadi setiap 30 epoch.

3. Pada evaluasi ketiga menggunakan 120 epoch, maka decay terjadi setiap 40 epoch.

4. Pada evaluasi keempat menggunakan 150 epoch, maka decay terjadi setiap 50 epoch.

5. Pada evaluasi kelima menggunakan 180 epoch, maka decay terjadi setiap 60 epoch. 


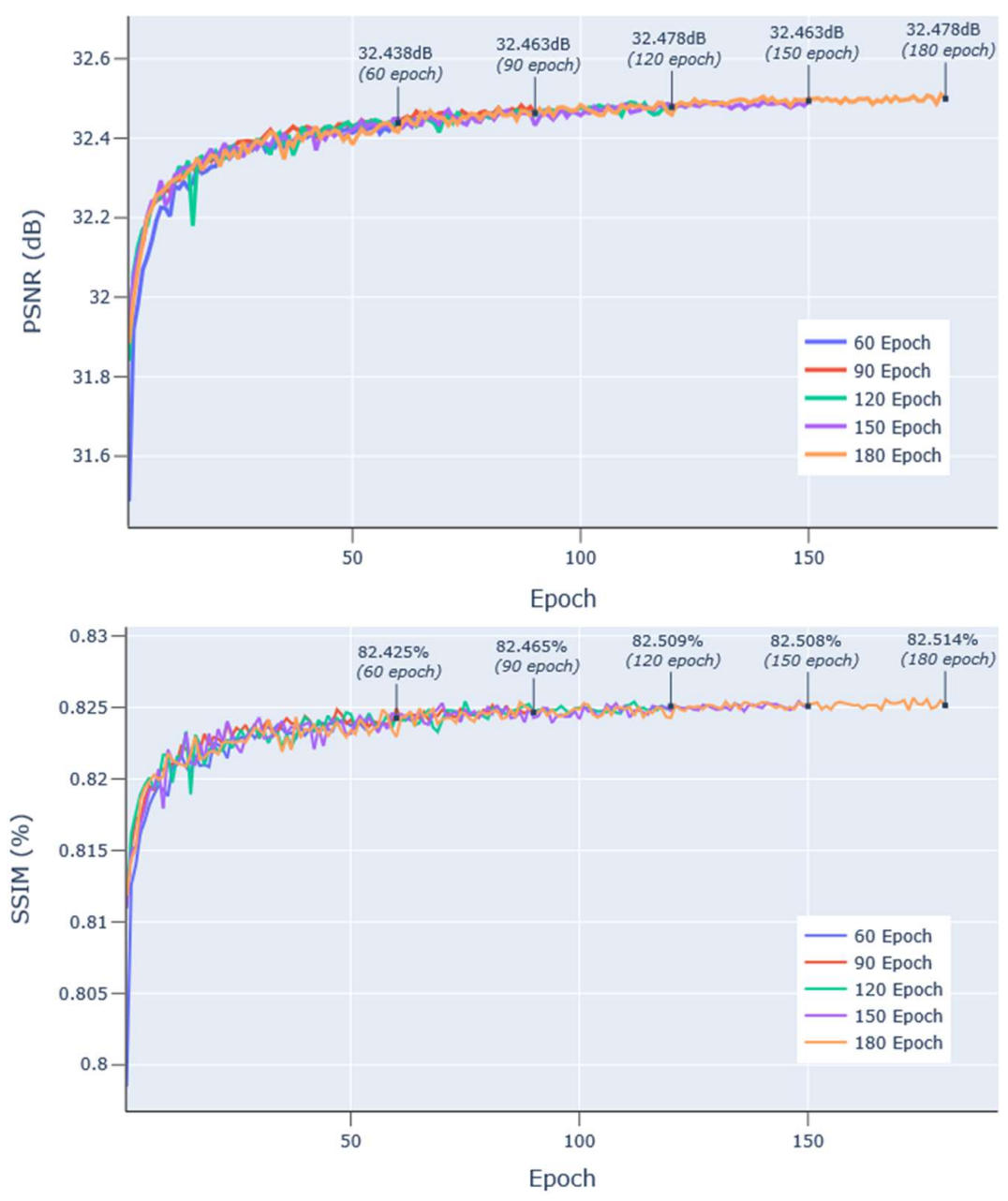

Gambar 10. Pengaruh Jumlah Epoch terhadap Performa PSNR (atas) SSIM (bawah)

Gambar 10 merupakan hasil pengujian dari pengaruh jumlah epoch terhadap performa sistem. Berdasarkan hasil dari evaluasi pertama hingga kelima, diperoleh bahwa semakin banyak jumlah epoch, maka nilai parameter PSNR dan SSIM menjadi relatif lebih tinggi. Merujuk pada Gambar 6 dapat diketahui bahwa terjadi fluktuasi pada nilai PSNR dan SSIM saat tahap pelatihan. Akan tetapi, terdapat tren yang meningkat dan relatif stabil ketika jumlah epoch diperbesar. Hal ini disebabkan oleh adanya transisi pada nilai learning rate. Berdasarkan Gambar 10, ketika nilai learning rate menjadi lebih kecil, fluktuasi yang terjadi cenderung lebih minimal.

\subsection{Tahap Pengujian Super Resolution}

Skenario ini merupakan tahap pengujian sistem Super Resolution untuk merekonstruksi citra udara menjadi ukuran yang sesuai dengan scale factor, yaitu: 2, 3 dan 4 kali lebih besar dari citra asli. Beberapa parameter pada model CNN yang digunakan, yaitu: dataset Aero_bsd300_6, 9 layer, 192 filter awal pada feature extraction network, dan 180 epoch. Pengujian ini menggunakan parameter globalpada Tabel 4. Gambar 11 merupakan hasil citra rekonstruksi untuk berbagai scale factor terhadap performa PSNR dan SSIM. Sedangkan Gambar 12 dan Gambar 13 merupakan tampilan hasil pengujian pada cuplikan fotogrametri untuk scale factor 2, 3 dan 4. 

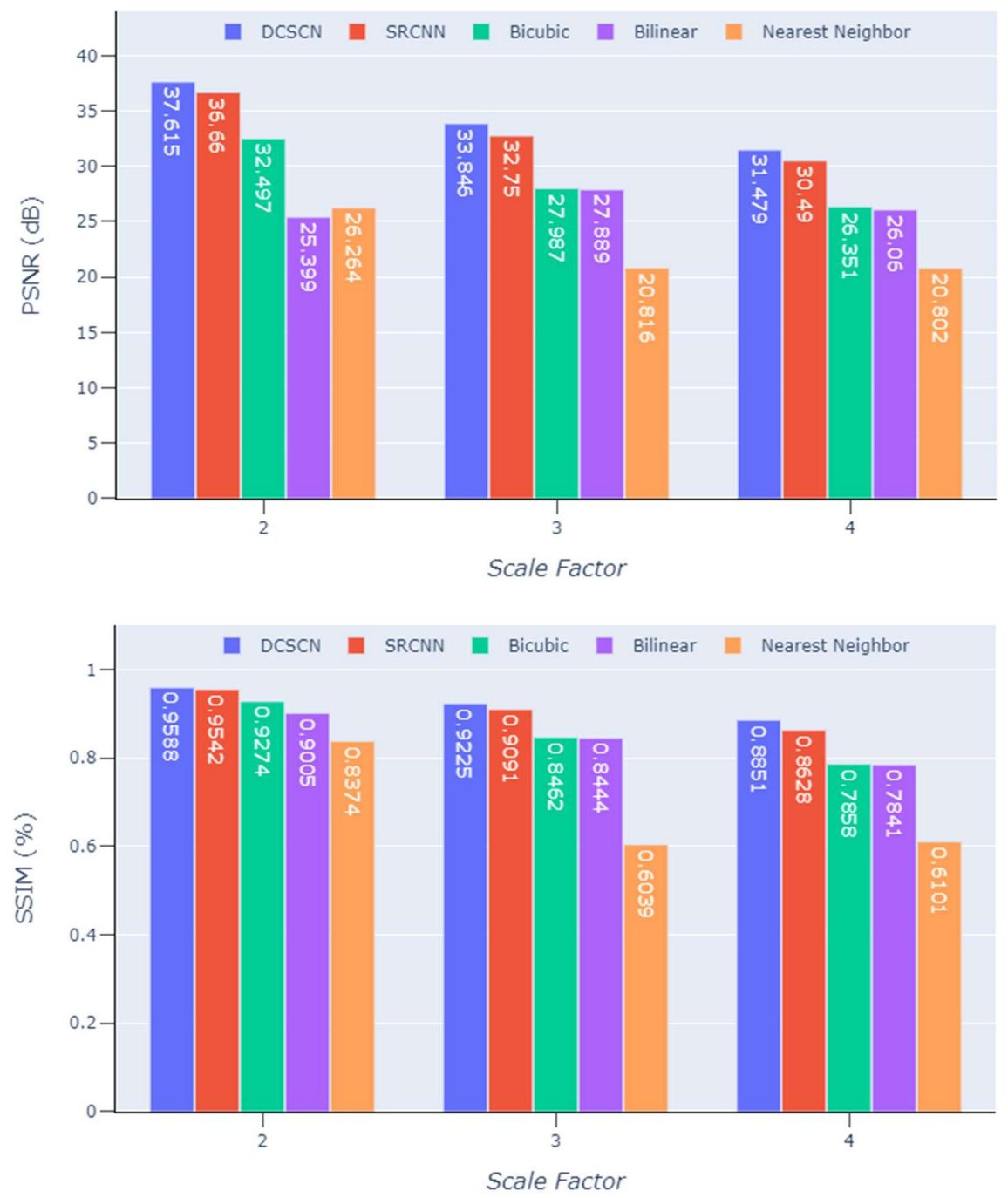

Gambar 11. Performa PSNR (atas) dan SSIM (bawah) pada Citra Hasil Rekonstruksi

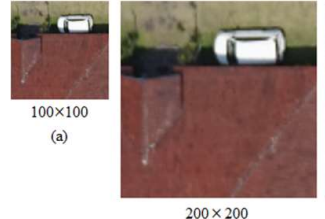

(b)

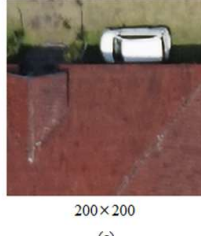

(c)

(1)

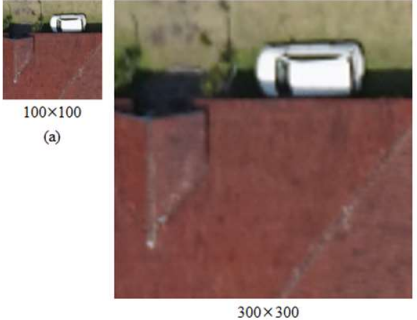

(2)

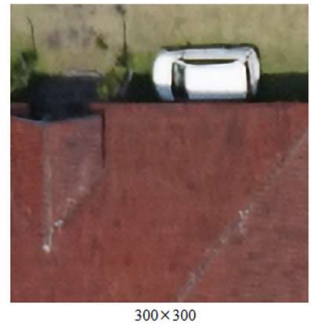

Gambar 12. Hasil Pengujian pada Cuplikan Fotogrametri (1) scale factor 2, (2) Scale Factor 3, (a) Citra Asli, (b) Interpolasi bicubic, (c) Super Resolution 

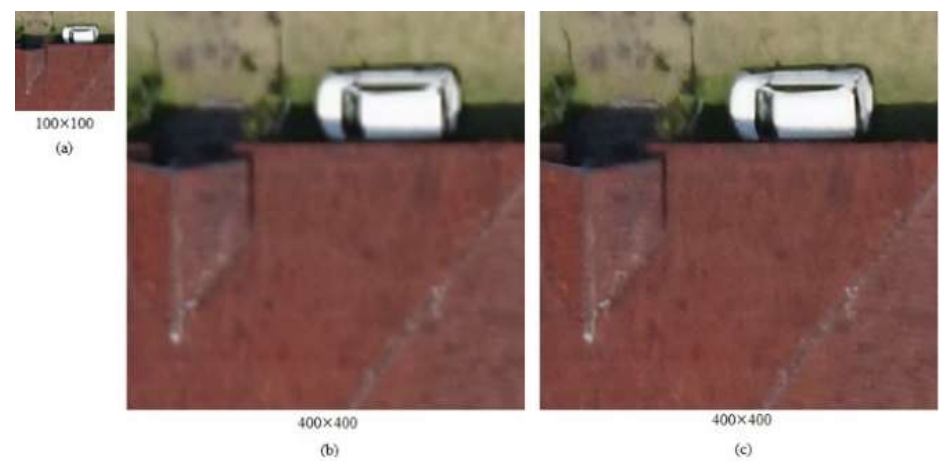

\section{Gambar 13. Hasil Pengujian pada Cuplikan Fotogrametri dengan Scale Factor 4} (a) Citra Asli (b) Interpolasi Bicubic (c) Super Resolution

Berdasarkan hasil evaluasi terhadap dataset Aero10, diperoleh bahwa model CNN yang telah dirancang berhasil mengungguli metode rekonstruksi dengan interpolasi bicubic. Tahap evaluasi juga dilakukan pada dataset Set5 untuk membandingkan antar metode rekonstruksi dengan model DCSCN, model SRCNN, interpolasi bicubic, interpolasi bilinear, dan interpolasi nearest neighbor. Hasil dari tahap evaluasi tersebut dapat diketahui bahwa model DCSCN berhasil mengungguli metode rekonstruksi lainnya. Pada Gambar 12 dan Gambar 13, model DCSCN juga diujikan untuk merekonstruksi citra yang telah di-downsampling, dan memberikan kualitas citra yang lebih baik.

\section{KESIMPULAN}

Penelitian ini menghasilkan sistem Super Resolution yang mampu merekonstruksi citra udara dari resolusi rendah menjadi citra udara resolusi tinggi menggunakan model DCSCN. Selain pada citra udara, dilakukan pula evaluasi terhadap nilai parameter PSNR dan SSIM menggunakan dataset Set5. Hasil model DCSCN mengungguli SRCNN, dengan nilai yang didapatkan pada scale factor 2, 3 dan 4, yaitu: 36.66dB / 0.9542, 32.75dB / 0.9090 dan 30.49dB / 0.8628. Sedangkan, pada penelitian ini didapatkan nilai PSNR dan SSIM sebesar 37.614dB / 0.9588, 33.846dB / 0.9225 dan 31.479dB / 0.8851. Untuk penelitian berikutnya, model Super Resolution dapat menggunakan fungsi optimizer Stochastic Gradient Descent (SGD). Optimizer SGD memiliki tingkat efektivitas yang baik dalam proses machine learning untuk melakukan deep learning. Fungsi optimizer ini bersifat stokastik atau mampu mengukur suatu peristiwa dengan data yang tidak stabil. Kemudian, sistem Super Resolution pada citra udara dapat diimplementasikan secara real-time. Data video yang ditangkap oleh UAV, selanjutnya dikirimkan secara langsung, dan diproses oleh sistem.

\section{DAFTAR RUJUKAN}

Ahn, H., Chung, B., \& Yim, C. (2019). Super-Resolution Convolutional Neural Networks Using Modified and Bilateral ReLU. International Conference on Electronics, Information, and Communication (ICEIC), (pp. 1-4).

Budiman, G., \& Novamizanti, L. (2015). White Space Steganography On Text By Using LZWHuffman Double Compression, International Journal of Computer Networks \& Communications, 72$), 136 \mathrm{~A}$. https://doi.org/10.5121/ijcnc.2015.7210.

Dong, C., Loy, C.C., He, K., \& Tang, X. (2016). Image Super-Resolution Using Deep 
Super Resolution pada Citra Udara menggunakan Metode Convolutional Neural Network

Convolutional Networks. IEEE Transactions on Pattern Analysis and Machine Intelligence, 38(2), 295-307. https://doi.org/10.1109/TPAMI.2015.2439281.

Fadnavis, S. (2014). Image Interpolation Techniques in Digital Image Processing: An Overview. International Journal of Engineering Research and Applications (IJERA), 4(10), 70-73.

Géron, A. (2017). Hands-On Machine Learning with Scikit-Learn and TensorFlow. Sebastopol: O'Reilly.

Heaton, J. (2015). Artificial Intelligence for Humans, Volume 3: Deep Learning and Neural Networks (1st ed.; T. Heaton, Ed.). Chesterfield: Heaton Research, Inc.

Nurfitri, K., \& Suyanto, M. (2016). Penilaian Kualitas Pemampatan Citra Pada Aplikasi-Aplikasi Instant Messenger. Jurnal Ilmiah Multitek Indonesia, 10(2), 78-90. https://doi.org/10.24269/mtkind.v10i2.346.

Lin, M., Chen, Q., \& Shuicheng, Y. (2014). Network In Network. Neural and Evolutionary Computing. arXiv: 1312.4400

Patel, P., Nandu, M., \& Raut, P. (2018). Initialization of Weights in Neural Networks. International Journal of Scientific Development and Research (IJSDR), 3(11), 73-79.

Sewak, M., Karim, Md. R., \& Pujari, P. (2018). Practical Convolutional Neural Networks. Birmingham: Packt Publishing Ltd.

Shahmoradi, J., Talebi, E., Roghanci, P., \& Hassanalian, M. (2020). A Comprehensive Review of Applications of Drone Technology in the Mining Industry. Drones 2020, 4(34), 1-25. https://doi.org/10.3390/drones4030034

Simonyan, K., \& Zisserman, A. (2015). Very Deep Convolutional Networks for Large-Scale Image Recognition. International Conference on Learning Representations (ICLR), (pp. 1-14).

Sun, Y., Zhang, W., Gu, H., Liu, C., Hong, S., Xu, W., \& Gui, G. (2019). Convolutional Neural Network Based Models for Improving Super-Resolution Imaging. IEEE Access, 7, 43042-43051. https://doi.org/10.1109/ACCESS.2019.2908501.

Stenroos, O. (2017). Object Detection from Images Using CNN. Aalto University.

Suyanto. (2018). Machine Learning Tingkat Dasar dan Lanjut. Penerbit Informatika.

Tong, T., Li, G., Liu, X., \& Gao, Q. (2017). Image Super-Resolution Using Dense Skip Connections. IEEE International Conference on Computer Vision (ICCV), (pp. 47994807). https://doi.org/10.1109/ICCV.2017.514. 
Welle, D. (2019, September 16). Bencana Alam di Indonesia Tahun 2019 Diprediksi Terus Terjadi. Retrieved from https://www.dw.com/id/bencana-alam-di-indonesia-tahun2019-diprediksi-terus-terjadi/a-46909297.

Wibawa, M. S. (2016). Pengaruh Fungsi Aktivasi, Optimisasi dan Jumlah Epoch Terhadap Performa Jaringan Saraf Tiruan. Jurnal Sistem Dan Informatika, 11(1), 167-174. https://doi.org/10.13140/RG.2.2.21139.94241.

Yamanaka, J., Kuwashima, S., \& Kurita, T. (2017). Fast and Accurate Image Super Resolution by Deep CNN with Skip Connection and Network in Network. 24th International Conference of Neural Information Processing (ICONIP), (pp. 217-225). 